PROCEEDINGS OF THE WORLD CONFERENCE ON OZONE THERAPY IN MEDICINE, DENTISTRY AND VETERINARY. ANCONA (ITALY). SEPTEMBER 22nd - 23rd - 24th, 2017

\title{
Effect of adding Ozone Sauna in Low Back Pain treatment [abstract]
}

\section{Tarek Tanbouli, Mazen Al-Qanni}

New Life Clinic, Mohandseen, Giza, Egypt.

\section{ABSTRACT}

\section{OPEN ACCESS}

\section{Citation}

Tanbouli T, Al-Qanni M. Effect of adding Ozone Sauna in Low Back Pain treatment [abstract]. Proceedings of The World Conference on Ozone Therapy in Medicine, Dentistry and Veterinary. Ancona (Italy). September 22nd - 23rd - 24th, 2017. J Ozone Ther. 2019;3(4):71-72. doi: 10.7203/ jo3t.3.4.2019.15545

\section{Academic Editor}

Jose Baeza-Noci,

School of Medicine, Valencia

University, SPAIN

\section{Editor}

World Federation of Ozone Therapy, Bolgna, ITALY

\section{Received}

June 17, 2019

Accepted

December 08, 2019

Published

December 30, 2019

\section{Intellectual Property}

Tarek Tanbouli.

This is an open access article distributed under the terms of the Creative Commons Attribution License (CC BY 4.0), which permits unrestricted use, distribution, and reproduction in any medium, provided the original author and source are credited.

\section{Author Information} drtanbouli@gmail.com
Purpose. To evaluate the effect of adding ozone sauna with local ozone $\left(\mathrm{O}_{3}\right)$ injection in low back treatment and comparing it to local $\mathrm{O}_{3}$ injection alone.

Material and Methods. This study was conducted on 40 patients suffering from chronic low back pain ( $<6$ month), (Age: 35-65 years.), (L1/L2 to L5/ S1), and Pain Assessment depends on Pain Scale before treatment and after 2, 4, 6, 8, 10, 12 sessions.

Patients are divided randomly into 2 groups; each with 20 patients (12 males and 8 females).

Group (A): received local $\mathrm{O} 3$ injection $(7-12 \mathrm{mcg} . / \mathrm{ml}$.) for 12 sessions twice weekly.

Group (B): received local O3 injection as group (A) followed by OZONE SAUNA for 12 sessions twice weekly.

Results. The results of the two treatment groups are shown in Tables 1 and 2 .

Table 1. Group A

\begin{tabular}{|c|c|c|c|c|c|c|c|c|c|}
\hline & \multicolumn{4}{|c}{ Pain Scale } & & No. of PT. their pain scale become \\
less than
\end{tabular}


Table 2. Group B

Pain Scale

\begin{tabular}{|c|c|c|c|c|c|c|c|c|c|}
\hline & \multicolumn{4}{|c}{ Pain Scale } & & No. of PT. their pain scale become \\
less than
\end{tabular}

Discussion. Previous studies were done proving that treating chronic low back pain by antibiotics for long periods gives good results.

Systemic effect of Ozone Sauna (its bactericidal effect [1]) could be the reason standing behind the fast and sustained improvement of patients receiving it and local ozone injections (its anti-inflammatory effect) at the same time.

Paravertebral local ozone injections 10-12 sessions, twice weekly (200-400mcg.) showed good results [2]:
A. $40 \%$ optimal improvement.
B. $35-40 \%$ marked improvement.
C. $15-25 \%$ minimal or no improvement.

Conclusion. Adding Ozone Sauna to local $\mathrm{O}_{3}$ injections in treating chronic low back pain resulted in fast improvement and better outcome (more patients) than using local $\mathrm{O}_{3}$ injections alone.

\section{References}

1. Albert HB, Sorensen JS, Christensen BS, Manniche C. Antibiotic treatment in patients with chronic low back pain and vertebral bone edema (Modic type 1 changes): a double-blind randomized clinical controlled trial of efficacy. Eur Spine J. 2013 Apr;22(4):697-707. doi: 10.1007/s00586-013-2675-y

2. Cinnella $P$, Brayda-Bruno M. La nostra esperienza nel trattamento dei conflitti disco-radicolari e delle radicolopatie post-chirurgiche con ossigeno-ozono terapia infiltrativa paravertebrale. Riv. Neuroradiol. 2001;14:75-79. 